\title{
MODEL KURIKULUM PROGRAM STUDI S-1 MANAJ EMEN INFORMASI KESEHATAN BERBASIS KERANGKA KUALIFIKASI NASIONAL INDONESIA
}

\author{
H osizah \\ Program Studi M anajemen Informasi K esehatan, Fakultas IImu-ilmu K esehatan Universitas E sa Unggul \\ Pembina A sosiasi Perguruan Tinggi Rekam M edis dan M anajemen Informasi Kesehatan Indonesia \\ (APTIRMIKI) \\ hozisah@esaunggul.ac.id
}

\begin{abstract}
Indonesian Qualifications Framework (IQF) established in 2012 refers the Indonesian embodiment on quality and national identity associated with national education and training system. IQF is levelling of competences and qualifications framework to reconcile, equalize, and integrate the fields of education and job training and work experience in order to award the work in accordance with the recognition of the competence structure of employment in various sectors. There are nine (9) levels of IQF qualifications, starting with the first is lowest to ninth qualification is highest. The Bachelor of Science Health Information Management at the sixth level of IQF which currently did not exist a core curriculum standard in Indonesia, therefore it was needed to formulate a Baccalaureate Degree Curriculum on Health Information Management Model based on IQF. This was conducted on Bachel or of Science Health Information Management Esa Unggul University J akarta in August-September 2016 by using the Guidelines of Curricul umDirectorate of Higher Education and Student Learning, Ministry of Research Technology and Higher Education Higher Education Republic Indonesia. There are 5 (five) the Bachelor of Health Information Management Profiles successfully established include A Specialist Coding Clinical, A Data Analyst and Manager of Health Information, A Manager of Health Information Management Department, A Special ist Clinical Documentation Improvement (CDI), An I nitiator on Designer and developer Electronic Health Records or Electronic Medical Records. Total credits 144 and eight semesters or four years.
\end{abstract}

Keywords: Health Information Management, Indonesian Qualifications Framework

\begin{abstract}
Abstrak
Kerangka Kualifikasi Nasional Indonesia (KKNI) ditetapkan tahun 2008 merupakan perwujudan mutu dan jati diri bangsa terkait dengan sistem pendidikan dan pelatihan nasional yang dimiliki Indonesia. KKNI adalah kerangka penjenjangan kualifikasi kompetensi y ang dapat meny andingkan, menyetarakan, dan mengintegrasikan antara bidang pendidikan dan bidang pelatihan kerja serta pengalaman kerja dalam rangka pemberian pengakuan kompetensi kerja sesuai dengan struktur pekerjaan di berbagai sektor. Ada 9 (sembilan) jenjang kualifikasi dalam KKNI, dimulai dari Kualifikasi 1 sebagai kualifikasi terendah dan kualifikasi 9 sebagai kualifikasi tertinggi. Program Studi S-1 Manajemen Informasi Kesehatan berada pada jenjang kualifikasi 6 (enam) KKNI yang saat ini di Indonesia belum memiliki standar nasional kurikulum inti, oleh karena itu perlu dilakukan pengabdian kepada masy arakat untuk memformulasikan model kurikulum S-1 Manajemen Informasi Kesehatan berbasis KKNI. Pengabdian masyarakat ini dilakukan pada program studi S-1 Manajemen Informasi Kesehatan Universitas Esa Unggul Jakarta bulan Agustus-September 2016 dengan menggunakan Panduan Penyusunan Kurikul umPendidi kan Tinggi DirektoratPembelajaran dan Kemahasiswaan, Kemenristekdikti. 5 (lima) profil lulusan S-1 Manajemen Informasi Kesehatan berhasil ditetapkan yaitu Spesialis Koding Klinis, Analis Data dan Manajer Informasi Kesehatan, Manajer Unit Kerja Manajemen Informasi Kesehatan (Rekam Medis dan Informasi Kesehatan), Spesialis Clinical Documentation Improvement (CDI), Inisiator Perancang dan Pengembang Rekam Kesehatan Elektronik (Electronic Health Records) atau Rekam Medis Elektronik (Electronic Medical Records). Beban studi 144 sks dan masa studi delapan semester.
\end{abstract}

K eywords: Manajemen Informasi Kesehatan, Kerangka Kualifikasi Nasional Indonesia 


\section{PENDAHULUAN}

Informasi kesehatan menupakan sumberdaya strategis dal amfasilitas kesehatan. Para pekerja dan manajer di bidang kesehatan perlu memahami kebutuhan dan nilai informasi kesehatan yang berkualitas agar dapat membantu dalam perencanaan, monitoring dan evaluasi serta pengambilan keputusan. Untuk memperolehinformasi kesehatan tersebut di butuhkan Manajemen Informasi Kesehatan mulai dari perolehan, analisis dan perlindungan informasi kesehatan yang diperlukan untuk meningkatkan kualitas pelayanan, keselamatan, privasi dan efisiensi pelayanan kesehatan (GHWC, 2016).

Manajemen I nformasi Kesehatan (Health I nformation Management) yang dikenal sejak tahun 1990-an merupakan paradigma baru dari Rekam Medis (Medical Record). Saatini di Indonesia sedang hangat diskusi perubahan nomenklatur Rekam Medis dan Informasi Kesehatan menjadi Manajemen Informasi Kesehatan. Beberapa fasilitas pelayanan kesehatan seperti numah sakit swasta sudah mengganti istilah Unit Keja Rekam Medis menjadi Unit Kerja Manajemen Informasi Kesehatan. Hal ini jugaterjadi dalamproses perubahan nomenklatur pendidi kan bidang studi Rekam Medis dan Informasi Kesehatan, dimana nomenklatur Rekam Medis dan Informasi Kesehatan di berlakukan untuk pendidikan level Diploma Tiga (D3) sedangkan Manajemen Informasi Kesehatan pada pendidikan level Diploma Empat (D4) atau Strata Satu (S-1) dan Strata Dua (S-2).

Program studi S-1 Manajemen Informasi Kesehatan Universitas Esa Unggul memperoleh ijin operasional melalui SK Menristekdikti No.272/K PT///201629 tanggal Agustus 2016. Kurikulum dibutuhkan sebagai bagian dari perangkat penyelenggaraan programstudi. Saat ini Kurikulum Inti pendidikan S-1 Manajemen Informasi Kesehatan belum ditetapkan oleh A sosiasi Perguruan Tinggi Rekam Medis dan Manajemen Informasi Kesehatan Indonesia (APTIRMIKI).

Dalam Panduan Penyusunan Kurikulum Pendidikan Tinggi yang dikeluarkan oleh Direktorat Pembelajaran danKemahasiswaan Kemennistekdikti 2016, kurikulum harus berbasis KKNI dengan tahapan meliputi: Perumusan Capaian Pembelajaran Lulusan (CPL), Pembentukan mata kuliah, Penyusunan Mata Kuliah dal amStruktur Kurikulum (Ditjen Dikti, 2016). Untuk itu diperlukan model Kurikulum Program Studi S-1 ManajemenI nformasi Kesehatan BerbasisKKNI yang dapat digunakan sebagai referensi bagi masyarakat dal am menyel enggarakan program studi sejenis.

\section{Kurikulum Pendidikan Tinggi}

Undang-undang No.12tahun2012tentang Pendi di kan Tinggi mengatur bahwa Pendidikan Tinggi terdiri dari Pendidikan Akademik, Pendidikan Vokasi dan Pendidikan Profesi. Pendidikan Akademik merupakan Pendidikan Tinggi program sarjana dan/atau program pascasarjana yang diarahkan pada penguasaan dan pengembangan cabang IImu Pengetahuan dan Teknologi. Program sarjana merupakan pendi di kan akademik yang di peruntukkan bagi lulusan pendidikan menengah atau sederajat sehingga mampu mengamalkan IImu Pengetahuan dan Teknologi melalui penalaran ilmiah. Program sarjana menyiapkan mahasiswa menjadi intelektual dan/atauilmuwanyang berbudaya, mampumemasuki dan/atau menciptakan lapangan kerja, serta mampu mengembangkan diri menjadi profesional.

Kerangka Kualifikasi Nasional Indonesia atau KKNI adalah kerangka penjenjangan kualifikasi kompetensi yang dapat menyandingkan, menyetarakan, dan mengintegrasikan antara bidang pendidikan dan bi dang pelatihan kerjasertapengal aman kerjadal am rangka pemberian pengakuan kompetensi kerja sesuai dengan struktur pekerjaan di berbagai sektor. KKNI terdiri atas 9 (sembilan) jenjang kualifikasi, dimulai dari jenjang 1 (satu) sebagai jenjang terendahsampai denganjenjang 9 (sembilan) sebagai jenjang tertinggi. Jenjang 1 sampai dengan jenjang 3 di kelompokkan dalamjabatan operator; jenjang 4 sampai dengan jenjang 6 dikelompokkan
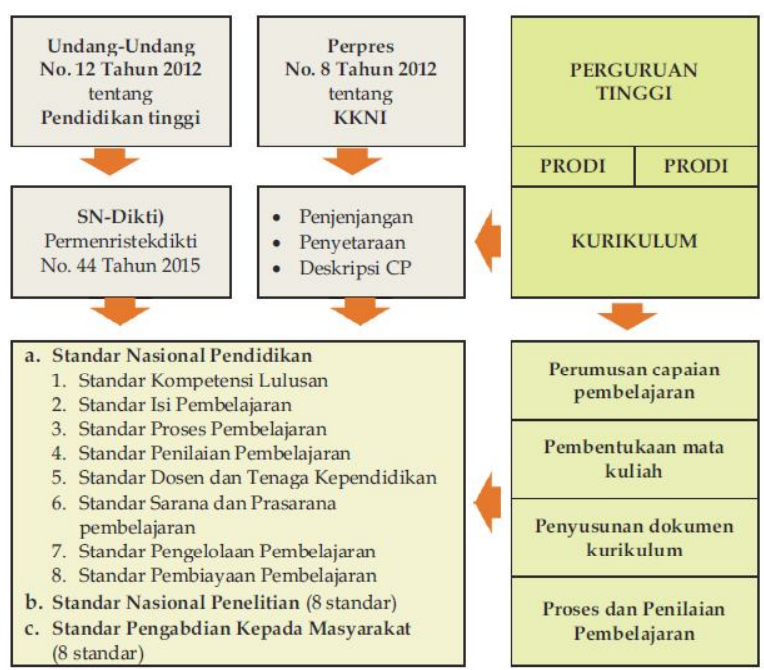

Gambar 1. Acuan dalam M engembangkan Kurikulum Pendidikan Tinggi (Sumber: Ditjen Dikti 2016). 
Kurikul um pendidikan Program Studi Sarjana Manaj emen Informasi Kesehatan berdasarkan CAHIIM (Commission Accreditation on Health Informaticsand Information Management) mencakup kompetensi sebagai berikut (CAHIIM, 2016).

Domain I. Data Content, Structure \& Standards (Information Governance) terdiri dari subdomain:

1. Classification Systems

2. Heal th Record Content and Documentation

3. Data Governance

4. Data Management

5. Secondary Data Sources

Domain II. Information Protection: Access, Disclosure, Archival, Privacy \& Security terdiri dari subdomain:

1. Health Law

2. Data Privacy, Confidentiality \& Security

3. Release of Information

Domain III. Informatics, Analytics and Data Use terdiri dari subdomain:

1. Heal th I nformation Technologies

2. Information Management Strategic Planning

3. Analytics and Decisi on Support

4. Heal th Care Statistics

5. Research Methods

6. Consumer Informatics

7. Heal th Information Exchange

8. Information Integrity and Data Quality

Domain IV. Revenue Management terdiri dari subdomain Revenue Cycle and Reimbursement

Domain V. Complianceterdiri dari subdomain:
1. Regulatory
2. Coding
3. Fraud Surveillance
4. Clinical Documentation I mprovement

Domain VI. Leadership terdiri dari subdomain:

1. Leadership Roles

2. Change Management

3. Work Design and Process I mprovement

4. Human Resources Management

5. Training and Development

6. Strategic and Organizational Management

7. Financial Management

8. Ethics

9. Project Management

10. Vendor/Contract Management

11. Enterprise Information Management
Supporting Body of Knowledge (Prerequisite or Evidence of Knowledge) terdiri dari:

1. Pathophysiology and Pharmacology

2. Anatomy and Physiology

3. Medical Terminology

4. Computer Concepts and Applications

5. Statistics

\section{K ompetensi Global Profesional Manajemen Informasi K esehatan}

Global Health Workforce Council (GHWC) merumuskan bahwa Professional Manajemen Informasi Kesehatan menjadi satu di antara tiga kelompok Profesi Informasi Kesehatan seperti gambar 2.

\section{Health Information Domains}

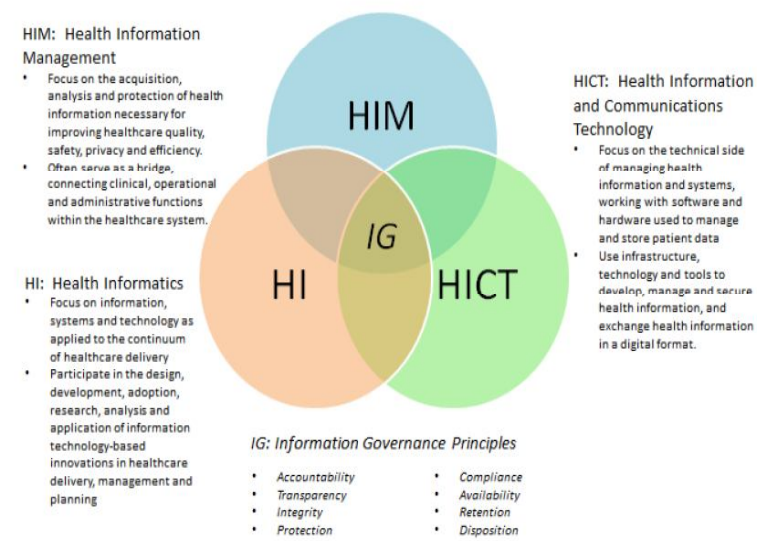

Gambar 2. Domain Profesi Informasi K esehatan (Sumber: G HW C , 2016)

Ada tiga domain Profesi Informasi Kesehatan meliput:

1. Health Information Management $(\mathrm{HIM})=$ Manaj emen I nformasi Kesehatan

.a Fokus pada perolehan, analisis dan perlindungan informasi kesehatan yang diperlukan untuk meningkatkan kualitas pelayanan kesehatan, keselamatan, privasi dan efisiensi.

b. Penghubung fungsi-fungsi klinis, operasional danadministratif dalamsistem pelayanan kesehatan

2. HealthInformatics $(\mathrm{HI})=$ InformatikaKesehatan

a. Fokus pada informasi, sistem dan teknologi yang digunakan dalampelayanan kesehatan. 
b. Berpartisipasi dalam perancangan, pengembangan, adopsi, riset, analisis dan aplikasi teknologi informasi dalam pelayanan kesehatan

3. Health Information and Communication Technology $(\mathrm{HICT})=$ Teknologi Informasi dan Komunikasi Kesehatan

a Fokus pada sisi teknis informasi, sistem dan teknologi dalam pengaturan sistem dan informasi kesehatan, bekerja dengan hardware dan software yang digunakan untuk mengel ola dan menyimpan data pasien.

b. Menggunakan infrastruktur, teknologi dan tool untuk mengembangkan, mengelola, mengamankan informasi kesehatan dan pertukaran informasi kesehatan dalam format di gital.

GHWC menetapkan level pendidikan untuk Profesi Informasi Kesehatan mulai dari Basic atau Entry (Associate Degree masa studi dua tahun), Intermediate (Baccalaureaute Degree masa studi empat tahun), dan Advanced (Master, Doctor Degree). Kompetensi yang telah ditetapkan bagi Profesional ManajemenInformasi Kesehatan sebagai berikut:

\section{Analytics and Statistics}

Analytics and Statistics: Analyze data to support decision-making, healthcare practice, and gain knowledge/busi ness intelligence through various methods and techniques such as data mining development of models, and statistical measurements. Understands availability and structure of internal and external data/ datasets, databases, and common healthcare statistics/biostatistics. Mayapplyanalytical and statistical techniques and/or interpretstatistics to support decision-making such as operations, heal thcare delivery, quality improvement, payment models, strategy, etc., and create business/health intel ligence.

2. Change Management

Understand the process of introducing change, getting it adopted, and diffusing it throughout the organisation. Ability to assess the implications of new solutions (including information and communication technology) and quantify benefits. Ability to maintain continuity throughout the change, monitor impact, take action, and refine approach as needed.
3. Classification of Disease, Coding Diagnoses and Procedures

Assign numeric and/or alphanumeric representations to clinical documentation to reflect medical conditions, health interventions, procedures and/or services in accordance with a designated classification system or code set and in compliance with related regulations/guidelines and ethical standards. Apply knowledge of how coded data for diagnoses, procedures and services are used in healthcare including for management, reporting, reimbursement, and research. Enable semantic interoperability between heal th information systems.

4. Clinical Documentation Improvement

Implement and utilize the CDI process to improve clinical documentation that will support coding, clinical care provision, data analysis and decision making.

5. Data Management and Governance Manageorganisational and health data through its lifecycle ensuring its availability, usability, integrity, and security to meet the needs of data users. Ensure data stewardship (custodianship) responsibilities are conceptualized and carried out through policies and processes for access, management, and permissible uses of data.

6. Data Quality and I nformation Integrity Maintain reliability and effectiveness of data for its intended uses including for caredelivery, operations, decision making, and planning. Establish processes to ensure that healthcare data are complete, accurate, consistent, timely, and secure from malicious or accidental modification or corruption.

7. Ethics

Understand and apply one's professional moral principles, theories and values in practice. For a healthcare organization this includes having programs (formal and informal) that support an ethical culture and decision-making processes to deal with the competing perspectives and obligations.

8. Financial Management Managementresponsibilitiesrelated to planning, organizing, directing andior controlling the financial activities of a department, business unit, or organization. 
9. Health Information Access, Disclosure, and Exchange

Create and apply strategies, policies, and processes related to heal th information access, discl osure, and exchangeincluding integration with related information systems and databases when appropriate.

10. Health Information Systems and Application Design and Planning

Specify, refine, update, produce, and make available a formal approach to implement information and communication technology solutions necessary to develop and operate the health information system architecture in suppor of the organisation priorities. Stay apprised of innovativesolutions for integration of new technology into existing products, applications, or services. Identify and clarify user needs (internal/external customers) and organisational policy to ensure system architecture and applications are in line with business requirements.

11. Health Information Systems and Application Development and Deployment

Engineer health information software and/ or hardware components to meet solution requirements such as specifications, costs, quality, time, energy efficiency, information security, and data protection. Integrate hardware, software or sub-system components into an existing or a new system Interpret the application design to develop a suitable application in accordance with customer needs. Code, debug, test and document, and communicate product development stages. I mplement software and hardware solutions, including installing, upgrading, or decommissioning.

12. Health Information Systems and Application Support

Takeproactiveaction to ensurestableand secure applications and health ICT infrastructure to avoid potential service disruptions induding proactive approaches to avoid or identify the root cause of ICT problems. Ensure efficient control and scheduling of softwareor hardware modifications to prevent multiple upgrades creating unpredictable outcomes. Respond to user requests and issues, recording relevant information. Assure resolution or escalate incidents and optimize system performance.
13. Health Law, Regulation, Accreditation, and Certification

Knowledge of applicable jurisdictional health law, regulation, accreditation standards and/ or certification requirements as relevant to the healthcare organization. Implementation of strategies to maintain compliance with applicable laws, regulations, standards, and requirements.

14. Health Record Content \& Documentation Maintain the patient's or client's health record as the official record of care, treatment, and services in accordance with applicable laws, regulations, and standards. Ensure that the health record contains complete and accurate relevant documentation and necessarymedical, health and wellness information (such as medical history, care or treatments received, test results, diagnoses, and medications taken) to meet the needs of the patient and their health team

15. Human Resources Management

Responsiblefor activities related to empl oyees, staffing, recruitment, training and development, performanceappraisal sin accordancewith the jurisdictional law and organization's strategic objectives, policies, and systems.

16. Information and Information Systems Governance

Define, deploy, and control the organisation-wide frameworkfor managing enterpriseinformation and the information systems throughout its lifecydein linewith theorganisation'sstrategy, operations, jurisdictional laws/regulatory, legal, risk, and environmental requirements. Create an information structure and deploy tools to capitalize on information assets and gain business.

17. Information Protection: Data Privacy, Confidentiality and Security

Understand applicable healthcare Iaw, regulation, and standards related to information protection of various stakeholders and able to develop related privacy, security, and confidentiality policies and develop/maintain an organizational infrastructure. Educate stakeholders on health information protection methods and their responsi bi lities.

18. Information Security Strategyand Management Define and make applicable a formal 
organisational strategy, scope, and culture to maintain safety and security of information including protected health information from external and internal threats (i.e., digital forensic for corporate investigations or intrusion investigation) and provide a platformfor information security management where security policies are implemented and continuously monitored/enhanced.

19. Organizational Management and Leadership Oversight and management of a department or organization applying processes of organizing, planning, leading, decision-making, and controlling resources in alignment with the overall business direction and strategic priorities of the organization.

20. Project Management

Leadand apply principles and proceduresrelated to project management that help control the activities associated with implementing a large undertaking to achieve a specific goal including planning and organizing, creating structured plans, project definitions, establishing time scales and milestones, tracking and analysis, revisions, changecontrols and communication. Ensure optimization of activities and resources.

21. Purchasing and Contracting Apply consistent procurement procedures to ensure that the entire purchasing process is fit for purpose, adds business value to the organization in compliance with legal and regulatory requirements. Define, validate, and makeapplicableservicelevel agreements (SLA) and contracts for health information related products and services.

22. Quality Management

Define, implement, and refine a formal strategy related to the quality of healthcare services and delivery, performance of business units or products (including ICT), and adherence with standards developed by external organizations. Implement quality policies to maintain and enhance serviceand product provision. Review qual ity performance indicators/measures and recommend enhancements to influence continuousqualityimprovement. Identify quality managemeyangnt accountability.

23. Research Design and Methods

Conduct, participate in and/or support healthrelated research aimed at systematically investigating and studying material and sources to establish facts and new information about a subject.

24. Risk Management

Implement the analysis and management of risk across information systems through the application of the enterprise defined risk management policy and procedure. Assess risk to the organization's business, and document potential risk and containment plans.

25. Standardsfor Data Content, Health Information Exchange, and Interoperability

Knowledgeand application of healthinformation technology standards for data content, health information exchange, and interoperability to facilitate an infrastructure where systems and applications can exchange data.

26. Strategic Planning

Align the organization's information and information system priorities with establ ished priorities, resources, common goals, and intended outcomes/results. Anticipatelong term business requirements and determine that the information governanceand information system model is in line with organization policy.

27. Training and Development

Design, implement, evaluate, and manage a plan designed to assist a department and or organization identify training needs of an empl oyee or employee group.

28. Work Design and Process I mprovement

Conduct workflow analysis for the purpose of improving processes and outcomes. Develop approaches to redesign workflow to achieve improvements.

29. Healthcare Delivery Systems

Understand the heal thcare delivery systemand international comparisons to give context to the learning program Therolesand responsibilities of key players within the health care network are discussed al ong with healthcare policy and strategies for provision of primary healthcare and the current and future challenges for the healthcare delivery system

\section{Capaian Pembelajaran (Learning Outcome) Program Sarjana}

Perhimpunan Profesional Perekam Medis dan Informasi Kesehatan Indonesia (PORMIKI) pada 
Kongres VIII di Makassar 17-21 Februari 2015, menetapkan kompetensi Perekam Medis dan Informasi Kesehatan (PMIK) sebagai perubahan dari standar kompetensi dalamSK Menkes No.377/ Tahun 2007 tentang Standar Profesi. Kompetensi PMIK terdiri dari: 1) Profesionalitas yang luhur, 2) Mawas diri dan pengembangan diri, 3) Manajemen Data Kesehatan, 4) Statistik Kesehatan, Riset Biomedis dan Manajemen Kualitas, 5) Organisasi Penyelenggara dan Pemberi Layanan Kesehatan, 6) Sistem dan Teknologi Informasi, 7) Organisasi dan Manajemen. Beberapa bulan kemudian terjadi perubahan kompetensi PMIK menjadi: 1) Profesional itas yang luhur, 2) Mawas diri dan pengembangan diri, 3) Komunikasi yang efektif, 4) Manajemen Data Kesehatan, 5) Pemanfaatan Ilmu Statistik Kesehatan untuk Riset Biomedis \& Manajemen Kual itas, 6) Manajemen Organisasi dan Kepemimpinan, 7) Pemanfaatan Teknologi untuk pengel olaan RMIK (PORMIKI, 2015).

Kompetensi PMIK yang diharapkan dalam manajemen rumah sakit seperti disampaikan oleh Djoti Atmojo (KARS) sebagai berikut:

1. Menyusun dan mengeval uasi standar mencakup standar Input, Proses dan Output (IPO).

2. Menyusun renstra RS/RKA/Programkerja RS/ Program kerja Unit kerja MIK.

3. Mengevaluasi kinerja, seperti kinerja RS, Unit kerja MIK dan lain-lain.

4. Melakukan perencanaan strategis.

5. Menghitung Indikator Klinis (asesmen pasien dan ketersediaan, isi dan penggunaan rekam medis).

6. Menghitung Indikator dal am Manajemen

7. Menghitung I ndikator Mutu (Penyusunan SPM)

8. Membuat dokumen terintegrasi

9. Membuat alternatif "discharge planning"

10. Merancang dan mengembangkan peraturan dan formulir rujukan pasien

11. Menyedi akan dokumen Asesmen Pasien

12. Menyediakn dokumen "proses asuhan pasien" meliputi: skrining, registrasi, asesmen awal, rencana asuhan, implementasi rencana asuhan, asesmen ulang, implementasi rencana asuhan, tranfer, rujukan, terminal, rencana pulang (ringkasan pulang).

13. Merancang formulir reconciliation.

14. Mampu memberikan contoh dan menawarkan formulir yang diperlukan dalam asuhan pasien (case manager).

15. MengejakanManajemenKomunikasi Informasi.
16. Melakukan Pencatatan Terintegrasi

17. Menjabarkan akses ke dalam RM atau rekam kesehatan.

18. Mengontrol dan mengawal konsistensi pelaksanaan standar akreditasi RS (Atmodjo, 2013).

\section{METODE}

Pengabdian masyarakat ini dilakukan di Program Studi S-1 Manajemen I nformasi Kesehatan Fakultas IImu-ilmuKesehatan UniversitasEsaUnggul Jakarta bulanAgustus-September 2016. Metode perancangan kurikulumProgramStudi S-1 Manajemen Informasi Kesehatan menggunakan panduan penyusunan kurikulum yang ditetapkan ol eh Ditjen Dikti 2016 seperti dalam gambar 3. Tahapan perancangan kurikulum berisi kegiatan penyusunan konsep sampai dengan penyusunan mata kul iah dal amsetiap semester Program Studi S-1 Manajemen Informasi Kesehatanyang di bagi kedal amtiga bagian kegiatan yaitu: 1) Perumusan capaian pembelajaran Iul usan (CPL); 2) Pembentukan matakuliah; 3) Penyusunan mata kuliah (kerangka kurikul um).

\section{Perumusan Capaian Pembelajaran Lulusan (CPL)}

ProgramStudi S-1 Manajemen Informasi Kesehatan Fakul tas IImu-ilmu Kesehatan Universitas Esa Unggul Jakarta merupakan program studi baru dengan SK Menristekdikti No.272/KPT/I/201629 tanggal Agustus 2016. Profil Iulusan Program Studi S-1 Manajemen Informasi Kesehatan mempertimbangkan lima aspek yaitu: 1) Kompetensi Perekam Medis dan Informasi Kesehatan (PMIK) hasil Kongres Perhimpunan Profesional Perekam Medis dan Informasi Kesehatan Indonesia (PORMIKI) VIII pada tanggal 17-21 Februari 2015 di Makassar Sulawesi Selatan, 2) Kompetensi Profesional Manajemen Informasi Kesehatan yang ditetapkan Global Health Workforce Council (GWHC), 3) Kurikul umpendidikan S-1 Manajemen Informasi Kesehatan yang ditetapkan Commission Accreditation on Health I nformatics and Information Management (CAHIIM), 4) Visi danMisi Universitas EsaUnggul, 5) Masukan dari TimKomisi Akreditasi Rumah Sakit (KARS).

Profil lulusan yang telah ditetapkan dijadikan acuan dal am menentukan rumusan CPL Program Studi S-1 Manajemen Informasi Kesehatan. Rumusan CPL disusun sesuai KKNI dan SN-Dikti ditambah 
dengan Capaian Pembelajaran atau Learning Outcome (LO) program S-1 kesepakatan antara PORMKI dan APTIRMIKI (Asosiasi Perguruan Tinggi Rekam Medis dan Manajemen Informasi Kesehatan I ndonesia).

\section{Pembentukan mata kuliah}

Pembentukan mata kuliah Program Studi S-1 Manajemen Informasi Kesehatan Fakultas IImuilmu Kesehatan Universitas Esa Unggul Jakarta dimulai dengan menentukan bahan kajian dan materi pembelajaran yang diperlukan untuk mencapai CPL meliputi: Sikap, Pengetahuan, Keterampilan Umum dan Keterampilan Khusus. Penetapan mata kuliah dan besarnya sks mata kuliah dilakukan setelah disepakati bahan kajian dan materi pembelajaran.

\section{Penyusunan Mata Kuliah dalam Struktur K urikulum.}

Struktur kurikulum Program S-1 Manajemen Informasi Kesehatan disusun mengacu pada SNDikti. Dalampasal 16 dijelaskan bahwa beban belajar program sarjana paling sedikit 144 (seratus empat puluh empat) sks. Tahap perancangan kurikulum ProgramStudi S-1 Manajemen Informasi Kesehatan Fakultas IImu-ilmu Kesehatan Universitas Esa Unggul J akarta secarasistematis dapat di li hat dalam gambar 3 berikut ini:

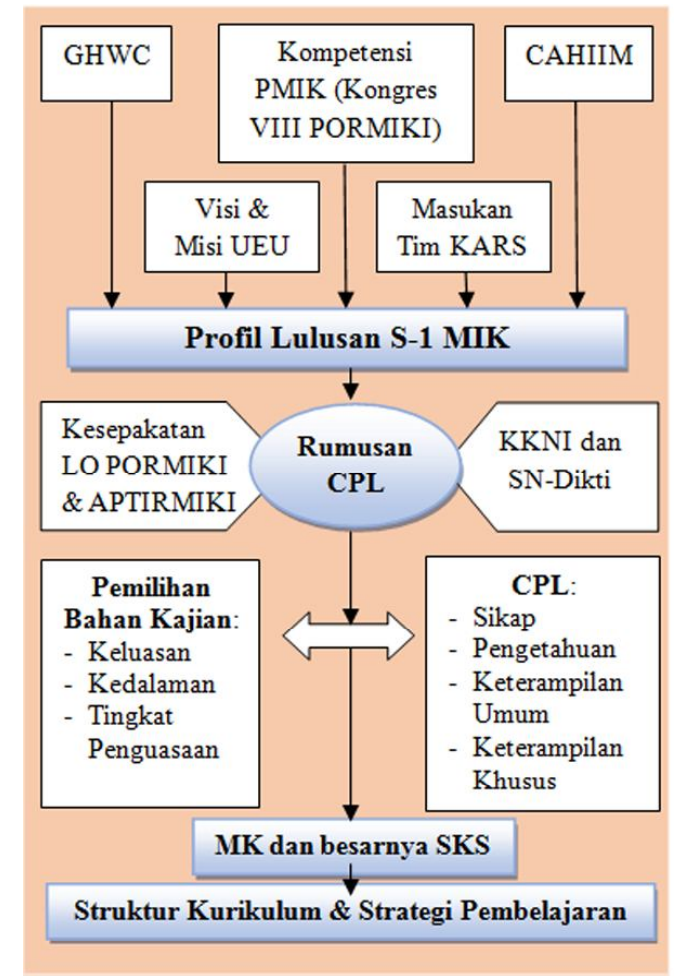

G ambar 3. Tahap Perancangan K urikulum Program Studi S-1 M anajemen Informasi K esehatan

\section{HASIL DAN PEMBAHASAN}

\section{Profil Lulusan Program Studi S-1 MIK}

ProgramStudi S-1 Manajemen I nformasi Kesehatan didirikan atas dasar kebutuhan tenaga PerekamMedis Ahli (PMA) dengan jenjang pangkat, golongan ruang dimulai dari Penata Muda, golongan ruang III/a seperti tercantum dalam Permenpan-RB No.30 Tahun 2013 tentang J abatan Fungsional Perekam Medis danAngka Kreditnya. DalamrumpunTenaga Kesehatan seperti tercantum pada Undang-undang RI No. 36 Tahun 2014 dijelaskan bahwa Perekam Medis telah direvisi menjadi Perekam Medis dan Informasi Kesehatan.

Profil lulusan Program Studi S-1 MIK dirumuskan dengan memperhatikan berbagai sumber seperti terlihat pada gambar 3 meliputi kompetensi professional Manajemen Informasi Kesehatan yang ditetapkan oleh PORMIKI, GHWC, CAHIIM, Visi-Misi UniversitasEsaUnggul dan satu di antara masukan dari pemangku kepentingan yaitu Komisi Akretasi RS (KARS). Ada 5 (lima) profil lulusan yang telah ditetapkan yaitu:

1. Spesialis Koding Klinis

2. Analis Data dan Manajer Informasi Kesehatan

3. Manajer Unit Kerja MIK (RMIK)

4. SpesialisClinical Documentation Improvement (CDI)

5. Inisiator Perancang dan Pengembang Electronic Health Records (EHR)/Electronic Medical Records (EMR).

\section{Capaian Pembelajaran Program Studi S-1} M anajemen Informasi Kesehatan (MIK)

Capaian pembelajaran Program Studi S-1 MIK disusun sesuai Kerangka Kualifikasi Nasional Indonesia (KKNI) level level 6 (enam). Rumusan capaian pembelajaran diperoleh melalui hasil kesepakatan antara Asosiasi Perguruan Tinggi RekamM edis dan Manajemen Informasi Kesehatan Indonesia (APTIRMIKI) dengan Dewan Pimpinan Pusat Perhimpunan Profesional PerekamMedis dan Informasi Kesehatan Indonesia (PORMIKI) pada tanggal 5-7 Juli 2015.

Deskripsi spesisik sesuai KKNI level level 6 telah disepakati pada programstudi S-1 sebagai berikut:

1. Mampu memanfaatkan IPTEK dan beradaptasi terhadap stituasi yang dihadapi dalam penyel esaian masalah dalam bi dang MIK.

2. Mampu Menguasai konsep teoritis secaraumum tentang pengetahuan biomedik, komunikasi, TI, 
manajemen yang bersifat khusus dalam manajemen data dan infomasi kesehatan secara mendal am serta mampu memformulasikan penyel esaian masalah prosedural.

3. Mampu mengambil keputusan yang tepat berdasarkan analisis informasi dan data pelayanan kesehatan dan memberikan petunjuk dalammemilih berbagai al ternatif solusi bi dang MIK.

4. Mampu bertanggungjawab terhadap pekerjaan UK MIK (RMIK) dandapatdiberi tanggungjawab atas pencapaian hasil keja MIK.

Sikap, pengetahuan, keterampilan umum, dan keterampilan khusus CPL Program Studi S-1 Manajemen Informasi Kesehatan berikut ini:

\section{Sikap}

Rumusan sikap sesuai SN-Dikti sebagai berikut:

1. Bertakwa kepada Tuhan Yang Maha Esa dan mampu menunjukkan sikap religious

2. Menjunjung tinggi nilai kemanusiaan dalam menjalankan tugas berdasarkan agama, moral, dan etika.

3. Berkontribusi dalam peningkatan mutu kehidupan bermasyarakat, berbangsa, bernegara, dan kemajuan peradaban berdasarkan Pancasila;

4. Berperan sebagai warganegara yang bangga dan cintatanah air, memiliki nasional ismesertarasa tanggungjawab pada negara dan bangsa;

5. Menghargai keanekaragaman budaya, pandangan, agama, dan kepercayaan, serta pendapat atau temuan orisinal orang lain;

6. Bekejasama danmemiliki kepekaan sosial serta kepedul ianterhadap masyarakat dan lingkungan;

7. Taat hukum dan disiplin dalam kehidupan bermasyarakat dan bernegara;

8. Menginternalisasi nilai, norma, dan etika akademik;

9. Menunjukkan sikap bertanggungjawab atas pekejaan di bi dang keahliannya secara mandiri; dan

10. Menginternalisasi semangat kemandirian, kejuangan, dan kewirausahaan.

\section{Pengetahuan}

Rumusan pengetahuan CPL Program Studi S-1 Manajemen Informasi Kesehatan adal ah wajib menguasai pilar IImu Biomedik, Manajemen dan Teknologi informasi komunikasi yang dapat dijadi kan landasar berpikir kritis dalamManajemen Informasi Kesehatan. Body of Knowledge pendukung sebagai prasyarat pada program studi ini adalah:
Patofisiologi dan Farmakologi, Anatomi dan Fisiologi, Terminologi Medis, Konsep dan A plikasi Komputer (CAHIIM, 2016) ditambah Komunikasi dan HukumKesehatan (GHWC, 2016).

\section{K eterampilan U mum}

Rumusan keterampilan umum sesuai SN-Dikti sebagai berikut:

1. Mampu menerapkan pemikiran logis, kritis, sistematis, dan inovatif dalam konteks pengembangan atau implementasi ilmu pengetahuan dan teknologi yang memperhatikan dan menerapkan nilai humaniora yang sesuai dengan bidang keahliannya;

2. Mampu menunjukkan kinerjamandiri, bermutu, dan terukur,

3. Mampu mengkaji implikasi pengembanganatau implementasi ilmu pengetahuan teknologi yang memperhatikan dan menerapkan nilai humaniora sesuai dengan keahliannya berdasarkan kaidah, tata cara dan etika ilmiah dalam rangka menghasilkan solusi, gagasan, desain atau kritik seni, menyusun deskripsi saintifik hasil kajiannya dalam bentuk skripsi atau laporan tugas akhir, dan mengunggahnya dalam laman perguruan tinggi

4. menyusun deskripsi saintifik hasil kajian tersebut di atas dalam bentuk skripsi atau laporan tugas akhir, dan mengunggahnya dal am laman perguruan tinggi;

5. Mampu mengambil keputusan secara tepat dal am konteks penyelesaian masal ah di bidang keahliannya, berdasarkan hasil anal isisinformasi dan data;

6. Mampu memelihara dan mengembang-kan jaringan kerja dengan pembimbing, kolega, sejawatbaik di dalammaupundi luar lembaganya;

7. Mampu bertanggungjawab atas pencapaian hasil kerja kelompok dan melakukan supervisi dan evaluasi terhadap penyelesaian pekerjaan yang ditugaskan kepada pekeja yang beradadi bawah tanggungjawabnya;

8. Mampu melakukan proses eval uasi diri terhadap kelompok kerja yang berada di bawah tanggung jawabnya, dan mampu mengel ol a pembelajaran secara mandi ir; dan

9. Mampu mendokumentasikan, menyimpan, mengamankan, dan menemukan kembali data untuk menjamin kesahihan dan mencegah plagiasi. 


\section{K eterampilan K husus}

Rumusan keterampilan khusus diadopsi kepakatan PORMIKI dan APTIRMIKI pada rapat tanggal 4-5 Juli 2016 di Jogyakarta dan diperkaya dengan rumusan kompetensi GHWC dan CAHIIM serta masukan stakeholder. Rumusan keterampilan khusus Program Studi S-1 Manajemen Informasi Kesehatan sebagai berikut:

1. Memvalidasi semua kunjungan yang ada di fasilitas pelayanan kesehatan (registrasi pasien rawat jal an dan rawat inap)

2. Merancang database pelayanan kesehatan

a Merancang sistem indeks pasien sesuai sistem yang digunakan (manual maupun elektronik)

b. Menjamin keamanan data kesehatan dari pelayanan kesehatan sesuai dengan hukum yang berlaku, peraturan dan standar.

3. Mengembangkan petunjuk pengorganisasian rekam medis dan informasi kesehatan

a Memelihara standar rekam medis dan informasi kesehatan sesuai dengan regul asi

b. Menyiapkan standar rekam medis dan informasi kesehatan untuk kepentingan akreditasi, perijinan rumah sakit dan sertifikasi.

C. Merancang dokumen klinis

4. Memilih aplikasi elektronik untuk sistem pengkodean dan klasifikasi klinis

5. Mengelola aplikasi proses pengkodean dan klasifikasi klinis

a Menjaga proses, kebijakan dan prosedur untuk memastikan keakuratan data yang telah dikode.

b. Mengel ola penggunaan data klinis yang diperlukan dalam sistem pembayaran prospektif (JKN) di pelayanan kesehatan.

c. Mengel ola penggunaan data klinis yang di perlukan dalamsistempenggantian biaya dalam pelayanan kesehatan.

6. Pengembanganaplikasi dan proseschargemaster dan manajemen klaim

7. Mengel ol a proses kelengkapan sistempelaporan

8. Menganalisis dan menyajikan data untuk manajemen mutu, manajemen utilisasi, manajemen risiko dan kepentingan lain yang terkait dengan asuhan pasien

9. Memanfaatkan perangkat lunak statistik

10. Analisis data klinis untuk mengidentifikasi tren yang menunjukkan peningkatan mutu, keselamatan pasien dan efektifitas asuhan pasien

11 Mengevaluasi dan menerapkan inisiatif informasi kesehatan nasional pada sistem penyelenggaraan asuhan pasien sesuai kebijakan dan prosedur sisteminformasi

12. Menafsirkan, mengkomunikasikan dan menerapkan hukum, akreditasi, perijinan dan standar sertifikasi yang terkait dengan inisiatif informasi kesehatan pelayanan kesehatan di tingkat daerah dan nasional

13. Merevisi prosedur dan kebijakan untuk memenuhi perubahan kebijakan dalam manajemen informasi kesehatan

14. Menterjemahkan dan menginterpretasikan informasi kesehatan untuk pelanggan dan pi hak ketiga.

15. Mengkoordinasikan pelaksanaan hukum dan persyaratan peraturan terkait dengan infrastruktur informasi kesehatan

16. Mengel ola akses dan pengungkapan informasi kesehatan individu

17. Mengembangkan dan menerapkan kebijakan dan prosedur kerahasiaan dan kemanan data secaraluas

18. Menerapkan dan mempromosikan praktek standar etik

19. Membangun dan memelihara petunjuk e-discovery (secara elektronik)

20. Mengel ola penggunaan teknologi, komuni kasi dan informasi komputer (hardware komponen, sistem jaringan arsitektur, sistem operasi dan termasuk hardware dan software untuk memastikan pengumpulan data, penyimpanan, anal isis dan pelaporan informasi

21. Berkontribusi dalam pengembangan jaringan, termasuk intranet dan internet aplikasi untuk memfasilitasi rekam kesehatan elektronik (EHR), rekam kesehatan pribadi (Personal Health Records=PHR), kesehatan masyarakat dan sistemadministrasi lainnya

a. Mentafsirkan urutan dan penggunaan standar untuk mencapai terselenggaranya sistem informasi kesehatan

b. Menerapkan pengetahuan desain dan arsitektur database (kamus data, model data, penyimpanan data, dsb) untuk memenuhi kebutuhan organisasi

c. Penggunaankosakataklinis danterminologi yang digunakan dalam organisasi sistem informasi kesehatan

d. Mengel olaindeks/database/registrasi klinis

e. Menerapkan secara tepat penggunaan teknologi el ektronik atau pencitraan untuk penyimpanan data/rekam medis

f. Menerapkan pengetahuan tentang teknik database query dan data mining untuk memfasilitasi pencarian informasi 
g. Merancang dan menghasilkan laporan administrasi dengan menggunakansoftware yang sesuai

h. Menerapkan teknologi elektronik atau pencitraan yang sesuai untuk penyimpanan data/rekam medis

i. Berpartisipasi dalam proses pemilihan sistem(RFI dan RFP)

j. Mengevaluasi dan merekomendasi administrasi klinis dan aplikasi pelayanan khusus (seleksi vendor RFP, RKE dan koding klinis)

22. Menerapkan sistem konsep siklus hidup, termasuk analisis sistem, desain, pelaksanaan, evaluasi dan pemeliharaan untuk pemilihan sisteminformasi asuhan kesehatan.

a Melindungi informasi kesehatan elektronik melalui langkah-langkah kerahasiaan dan keamanan

b. Melindungi integritas dan validitas data dengan menggunakanteknologi perangkat lunak atau perangkat keras

c. Menerapkan dan memantau data organi sasi unit kerja, kebijakan dan keamanan sistem informasi

d. Merekomendasikan unsur yang harus masuk dalam desain audit dan program pemantauan kualitas data

23. Mengelola sumber daya manusia untuk memfasilitasi perekrutan staf, retensi, dan pengawasan

a Memastikan kepatuhan dengan hukum ketenagakerjaan

b. Mengembangkan dan melaksanakan orientasi staf dan program pelatihan

c. Mengembangkan standar produktifitas untuk fungsi informasi kesehatan

d. Memantau tingkat produktifitas staf dan memberikan umpan balik kepada staf tentang kinerja

e Menganalisis datakinejastaf dal amtenaga kerja organisasi

24. Menerapkan al at manaj emen mutu

25. Mengembangkan, memotivasi dan mendukung kerjatim

26. Menjelaskan pengetahuan tentang manajemen keuangan dan prinsip prinsip akuntansi

a Menyiapkan dan memantau anggaran dan kontrak kerja sama

b. Menjelaskan dan menerapkan pengetahuan teknik anal isis manfaatbiaya (Cost Benefit Analysis) untuk kepastian kebutuhan sumber daya c. Mengel ola pengodean secara luas dan proses siklus pendapatan

27. Menyusun perencanaan strategis dan pengorganisasian

a. Menerapkan prinsip-prinsip umum manajemen dalamadministrasi pelayanan informasi kesehatan.

b. Menetapkan proyek dan tugas untuk staf yang sesuai.

c. Memfasilitasi manajemen proyek dengan mengintegrasikan upaya kerja, seperti perencanaan, pelaksanaan tugas dan kegiatan proyek.

d. Mendemonstrasikan keterampilan kepemimpinan.

28. Menganalisis data untuk mendukung pengambilan keputusan, praktik pelayanan kesehatan, dan mendapatkan pengetahuan/ intelijen bisnis melalui berbagai metode dan teknik seperti model-model pengembangan data mining, dan pengukuran statistik. Memahami struktur dan ketersediaan data/data set, data dasar (databases) internal dan eksternal, dan statistik/biostatistik pelayanan kesehatan. Menerapkanteknikstatistik dananalisis, dan/atau menginterpretasikan statistik untuk mendukung pembuatan keputusan seperti pelaksanaan, pemberian pelayanan kesehatan, peningkatan mutu, mode pembayaran, strategi, danlain lain, dan menciptakan intelejen bisnis/kesehatan.

29. Memahami proses manajemen perubahan, mengadopsinya dan menyebarkan ke seluruh organisasi. Mampu menilai implikasi solusi baru (termasuk teknologi komunikasi dan informasi) dan dapat mengukur manfaatnya. Mampu mempertahankankelangsungan seluruh perubahan, memantau dampak, mengambil tindakan, dan memperbaiki pendekatan yang di perlukan.

30. Menetapkan representasi numerik dan/atau alfanumerik pada dokumentasi klinis yang mencerminkan kondisi medis, intervensi kesehatan, prosedur dan/atau layanan sesuai dengan sistem klasifikasi yang ditunjuk atau kode set dan memenuhi peraturan terkait/ pedoman dan standar etika. Menerapkan pengetahuan bagaimana data kode diagnosis, prosedur dan layanan digunakan dal am pelayanan kesehatan termasuk untuk manajemen, pelaporan, penggantian pembayaran (reimbursement), dan penelitian. Memungkinkan interoperabilitas semantik di antara sisteminformasi kesehatan. 
31. Melaksanakan dan memanfaatkan proses peningkatan dokumentasi klinis (Clinical Documentation Improvement) yang dapat mendukung Koding, Pelayanan Klinis, Analisis Data dan Pembuatan Keputusan.

32. Mengel ola data organisasi dan data kesehatan melalui siklus hidupnya, memastikan ketersediaannya, kegunaan, integritas, dan keamanan untuk memenuhi kebutuhan pengguna data. Menjamin tanggung jawab kepengurusan Data dikonsep dan dilaksanakan melalui kebijakan dan proses untuk akses, manajemen, dan penggunaan data yang diperbolehkan.

33. Menjaga efektivitas dan reliabilitas data untuk penggunaannya termasuk untuk pemberian perawatan, operasional, pengambilan keputusan, dan perencanaan. Menetapkan proses untuk memastikan bahwa data pelayanan kesehatan lengkap, akurat, konsisten, tepat waktu, dan aman dari modifikasi berbahaya atau tidak disengaja.

34. Memahami dan menerapkan prinsip moral, teori dan nilai-nilai profesional seseorang dalam praktek. Pada organisasi pelayanan kesehatan hal ini termasuk memiliki program (formal dan informal) yang mendukung budaya etis dan proses pengambilan keputusan berkaitan dengan perspektif dan kewaji ban bersaing.

35. Tanggung jawab manajemen yang berkaitan dengan perencanaan, pengorganisasian, mengarahkan dan/atau mengendalikan kegiatan keuangan departemen, unit bisnis, atau organisasi.

36. Menciptakan dan menerapkan strategi, kebijakan, dan proses terkait dengan akses, pelepasan, dan pertukaran informasi kesehatan termasuk integrasi dengan sisteminformasi dan database jika memadai.

37. Menentukan, memperbaiki, memperbarui, memproduksi, dan menyediakan pendekatan formal untuk menerapkan solusi teknologi informasi dan komunikasi yang diperlukan untuk mengembangkan dan mengoperasikan arsitektur sistem informasi kesehatan dalam mendukung prioritas organisasi. Menetapkan solusi inovatif untuk integrasi teknologi baru kedal am produk yang sudah ada, apli kasi, atau layanan. Mengidentifikasi dan memperjelas kebutuhan pengguna (pelanggan internal/ eksternal) dan kebijakan organisasi untuk memastikan arsitektur sistem dan aplikasi yang sesuai dengan kebutuhan bisnis.
38. Mengetahui tentangyurisdiksi hukumkesehatan yang berlaku, regulasi, standar akreditasi danV atau persyaratan sertifikasi y ang relevan dengan organisasi kesehatan. Melaksanakan strategi untuk menjaga kepatuhan terhadap hukumyang berlaku, peraturan, standar, dan persyaratan.

39. Menjaga rekam kesehatan pasien atau klien sebagai catatan resmi dari perawatan, pengobatan, dan layanan sesuai dengan hukum, peraturan, dan standar yang berlaku. Menjamin bahwa rekam kesehatan berisi dokumentasi yang lengkap, akurat, relevan dan diperlukan medis, kesehatan dan informasi kesehatan (seperti riwayat kesehatan, perawatan atau pengobatan yang diterima, hasil tes, diagnosis, dan obat yang diberikan) untuk memenuhi kebutuhan pasien dan tim kesehatan.

40. Mendefinisikan, menyebarkan, dan mengendal ikankerangkakerjaorgani sasi untuk mengel ola informasi perusahaan dan sistem informasi di seluruh siklus hidup sejalan dengan strategi organisasi, operasi, hukum yurisdiksi/ peraturan, hukum, risiko, dan persyaratan lingkungan. Membuat struktur informasi dan menyebarkan alat untuk memanfaatkan aset informasi dan keuntungan bisnis.

41. Memahami hukum kesehatan yang berlaku, regulasi, dan standar yang berkaitan dengan perlindunganinformasi dari berbagai pemangku kepentingan dan mampu mengembangkan privasi, keamanan, dan kebijakan kerahasiaan terkait dan mengembangkan/mempertahankan infrastruktur organisasi. Mendi di k stakehol der pada metodeperlindungan informasi kesehatan dan tanggung jawabnya.

42. Mendefinisikan dan membuat strategi organisasi formal yang berlaku, ruang lingkup, dan budaya untuk menjaga keselamatan dan keamanan informasi termasuk melindungi informasi kesehatan dari ancaman eksternal dan internal (yaitu, forensik digital untuk investigasi perusahaan atau investigasi intrusi) dan menyediakan platform untuk manajemen keamanan informasi di mana kebijakan keamanan diimplementasikan dan dipantau terus-menerus/ditingkatkan.

43. Memimpin dan menerapkan prinsip-prinsipdan prosedur yang berkaitan dengan manajemen yang membantu mengontrol aktivitas yang berhubungan dengan pelaksanaan usaha besar untuk mencapai tujuan tertentu termasuk perencanaan dan pengorganisasian proyek, 
menciptakan rencana terstruktur, definisi proyek, menetapkan skala waktu dan target pencapaian, pelacakan dan analisis, revisi, mengubah kontrol dan komunikasi. Menjamin optimalisasi kegiatan dan sumber daya

44. Menerapkan prosedur pengadaan yang konsisten untuk memastikan bahwa proses seluruh pembelian cocok sesuai tujuan, menambah nilai bisnis untuk organisasi sesuai dengan persyaratan hukum dan peraturan. Mendefinisikan, memvalidasi, membuat perjanjian dan kontrak untuk produk dan layanan terkait informasi kesehatan.

45. Mendefinisikan, mel aksanakan, dan menyempurnakan strategi formal yang terkait dengan kualitas layanan kesehatan, kinerja unit bisnis atau produk (termasuk TIK), dan kepatuhan dengan standar yang dikembangkan ol eh organisasi eksternal. Menerapkan kebijakan kualitas untuk mempertahankan dan meningkatkan pelayanan dan penyediaan produk. Mereview indikator/ukuran kualitas kinerja dan merekomendasi kan pengembangan untuk mempengaruhi peningkatan mutu yang berkelanjutan. Mengidentifikasi akuntabilitas manajemen mutu.

46. Melaksanakan, berpartisipasi dan/atau mendukung penelitian yang berhubungan dengan kesehatan yang bertujuan menyelidiki dan mempelajari materi dan sumber untuk membangun fakta dan informasi baru tentang subjek penelitian.

47. Melaksanakan analisis dan manajemen risiko dalam sistem informasi melal ui penerapan kebijakan dan prosedur manajemen risiko perusahaan. Menilai risiko untuk bisnis organisasi, dan mendokumentasikan potensi risiko dan rencana pengendalian.

48. Mengetahui dan menerapkan standar teknologi informasi kesehatan untuk konten data, pertukaran informasi kesehatan, dan interoperabilitas untuk memfasilitasi infrastruktur di mana sistem dan aplikasi dapat bertukar data.

49. Menyelaraskan prioritas informasi dan sistem informasi prioritas organisasi dengan ketetapan prioritas, sumber daya, tujuan, dan hasil yang diharapkan. Mengantisipasi kebutuhan bisnis jangka panjang dan menentukan bahwa model tatakel ola informasi dan sistem informasi sejal an dengan kebijakan organisasi.
50. Melakukan analisis alur kerja untuk tujuan memperbaiki proses dan hasil. Mengembangkan pendekatan untuk merancang ulang alur kerja untuk mencapai perbai kan.

51. Memahami sistem pelayanan kesehatan dan berperan serta bertanggung jawab sebagai pemain kunci dalam jaringan pelayanan kesehatan bersama dengan kebijakan dan strategi kesehatan untuk penyediaan layanan kesehatan.

\section{Struktur K urikulum Program Studi S-1 MIK}

Sikap, pengetahuan, keterampilan umum, dan keterampilan khusus yang dibutuhkan dalam CPL telah dikemas dal ambeberapa mata kul iah dan bahan kajiannya. Pengel ompokkan mata kuliah dan beban studi ProgramS-1 Manajemen Informasi Kesehatan Universitas Esa Unggul telah ditetapkan dalam struktur kurikulumberikut ini:

\begin{tabular}{|c|c|c|c|}
\hline \multicolumn{4}{|c|}{ Capaian Pembelajaran L ulusan (CPL) dan M ata Kuliah } \\
\hline \multicolumn{4}{|l|}{ Sikap } \\
\hline Kode & Nama M ata K uliah & $\begin{array}{l}\text { Bobot } \\
\text { (sks) }\end{array}$ & Smt \\
\hline ESA 233 & Pendidikan A gama & 2 & 1 \\
\hline ESA 104 & Pancasila & 2 & 1 \\
\hline ESA 105 & Pendidikan Kewarganegaraan & 2 & 5 \\
\hline ESA 113 & Bahasa Indonesia & 2 & 1 \\
\hline MIK 491 & Etika Profesi & 2 & 4 \\
\hline KRK 271 & Komunikasi Efektif & 2 & 1 \\
\hline ESA 132 & TOEFL 1 & 2 & 1 \\
\hline ESA 133 & TOEFL 2 & 2 & 2 \\
\hline ESA 134 & Business English & 2 & 3 \\
\hline ESA 141 & Motivasi Usaha & 1 & 1 \\
\hline ESA 142 & Kewirausahaan & 2 & 5 \\
\hline MIK 291 & $\begin{array}{l}\text { Pelayanan Prima dal am Pelayanan } \\
\text { Kesehatan }\end{array}$ & 2 & 2 \\
\hline \multicolumn{4}{|c|}{ Pengetahuan } \\
\hline MIK 106 & Aljabar Linier & 2 & 1 \\
\hline ESA 162 & Sosiologi & 2 & 7 \\
\hline MIK 331 & Teori dan Perilaku Organisasi & 2 & 3 \\
\hline MIK 492 & Psikologi & 2 & 4 \\
\hline MIK 111 & Biologi & 2 & 1 \\
\hline MIK 212 & Anatomi \& Fisiologi 1 & 2 & 2 \\
\hline MIK 311 & Anatomi \& Fisiologi 2 & 2 & 3 \\
\hline
\end{tabular}




\begin{tabular}{|c|c|c|c|}
\hline MIK 213 & Patologi 1 & 2 & 2 \\
\hline MIK 314 & Patologi 2 & 2 & 3 \\
\hline IMF 372 & Farmakol ogi Terapan & 2 & 4 \\
\hline \multicolumn{4}{|c|}{ K eterampilan U mum } \\
\hline MIK 215 & Terminologi Medis 1 & 2 & 2 \\
\hline MIK 312 & Terminologi Medis 2 & 2 & 3 \\
\hline MIK 141 & Konsep Dasar MIK (Rekam Medis) & 2 & 1 \\
\hline MIK 151 & $\begin{array}{l}\text { Pengantar Teknologi Informasi } \\
\text { Komunikasi }\end{array}$ & 2 & 1 \\
\hline MIK 252 & Algoritma \& Pemrograman & 2 & 2 \\
\hline UST 153 & Statistik I (Statistik Deskriptif) & 2 & 3 \\
\hline ESA 155 & Statistik II (Statistik Inferens) & 2 & 4 \\
\hline MIK 691 & Metodologi Riset & 2 & 6 \\
\hline MIK 521 & Epidemiologi dan Surveilance & 2 & 5 \\
\hline MIK 522 & $\begin{array}{l}\text { Aspek Hukum dalam Pelayanan } \\
\text { Kesehatan }\end{array}$ & 2 & 5 \\
\hline \multicolumn{4}{|c|}{ K eterampilan K husus } \\
\hline MIK 216 & KKPMT I & 2 & 2 \\
\hline MIK 313 & KКРMT II & 2 & 3 \\
\hline MIK 414 & KKРMT III & 2 & 4 \\
\hline MIK 511 & Audit dan Evaluasi Koding Klinis & 2 & 5 \\
\hline MIK 612 & Koding Klinis dan Reimbursement & 2 & 6 \\
\hline MIK 422 & Statistik dalam MIK & 2 & 4 \\
\hline MIK 623 & Analisis dan Teknik Presentasi Data & 2 & 6 \\
\hline MIK 624 & Sistem Informasi Geografis & 2 & 6 \\
\hline MIK 721 & Analisis dan Teknik Pemodelan & 2 & 7 \\
\hline MIK 722 & $\begin{array}{l}\text { Proteksi dan Pertukaran Informasi } \\
\text { Kesehatan }\end{array}$ & 2 & 7 \\
\hline MIK 723 & Manajemen Data Penelitian & 2 & 7 \\
\hline MIK 625 & $\begin{array}{l}\text { Tata Kelola Sistem dan Informasi } \\
\text { Kesehatan }\end{array}$ & 2 & 6 \\
\hline MIK 242 & Standar Isi \& Pendokumentasian RM & 3 & 2 \\
\hline MIK 341 & $\begin{array}{l}\text { Pengel olaan Paper-based Rekam } \\
\text { Medis }\end{array}$ & 3 & 3 \\
\hline MIK 541 & Audit Dokumentasi Klinis 1 & 2 & 5 \\
\hline MIK 642 & Audit Dokumentasi Klinis 2 & 2 & 6 \\
\hline MIK 442 & RekamKesehatan Elektronik 1 & 2 & 4 \\
\hline MIK 543 & RekamKesehatan Elektronik 2 & 2 & 5 \\
\hline MIK 432 & Manajemen Mutu dan Risiko & 2 & 4 \\
\hline MIK 631 & $\begin{array}{l}\text { Standar A kreditasi Pel ayanan } \\
\text { Kesehatan }\end{array}$ & 2 & 6 \\
\hline MIK 532 & Manajemen Sumber Daya Manusia & 2 & 5 \\
\hline
\end{tabular}

\begin{tabular}{|c|c|c|c|}
\hline MIK 633 & $\begin{array}{l}\text { Disain Keja dan Peningkatan Proses } \\
\text { MIK }\end{array}$ & 3 & 6 \\
\hline MIK 634 & Manajemen Keuangan & 2 & 7 \\
\hline MIK 351 & $\begin{array}{l}\text { Manajemen Basis Data dan A plikasi } \\
\text { dalamMIK }\end{array}$ & 3 & 3 \\
\hline MIK 551 & Perancangan Sistem Informasi & 3 & 5 \\
\hline MIK 751 & $\begin{array}{l}\text { Standarisasi Data dan Interoperabi- } \\
\text { litas }\end{array}$ & 2 & 7 \\
\hline MIK 452 & Analisis danEval uasi SistemI nformasi & 2 & 4 \\
\hline MIK 292 & PKL 1 (Tahun ke-1) & 2 & 2 \\
\hline MIK 493 & PKL 2 (Tahun ke-2) & 2 & 4 \\
\hline MIK 791 & Magang (Tahun ke-3) & 4 & 7 \\
\hline MIK 892 & Skripsi & 6 & 8 \\
\hline & Total SK S & 136 & \\
\hline \multicolumn{4}{|c|}{ M ata K uliah Pilihan } \\
\hline MIK 750 & $\begin{array}{l}\text { Cloud Computing dan HL } 7 \text { dalam } \\
\text { Pelayanan Kesehatan }\end{array}$ & 2 & 7 \\
\hline MIK 650 & Telemedi cine dan e-Health & 2 & 6 \\
\hline MIK 550 & $\begin{array}{l}\text { Aspek Keamanan dan Kerahasiaan } \\
\text { SI/SIRS }\end{array}$ & 2 & 5 \\
\hline MIK 530 & Manajemen Proyek SI & 2 & 5 \\
\hline MIK 730 & Renstra dan Manajemen Perubahan & 2 & 7 \\
\hline MIK 720 & SistemInformasi Keperilakuan & 2 & 7 \\
\hline MIK 620 & Data Mining & 2 & 6 \\
\hline MIK 610 & Audit Medis & 2 & 6 \\
\hline & Total SKS & 16 & \\
\hline
\end{tabular}

\section{Matriks Mata K uliah dengan Profil Lulusan} Program S-1 M anajemen I nformasi K esehatan

\begin{tabular}{|c|c|c|}
\hline Profil Iulusan & Kode MK & Nama M K \\
\hline \multirow{12}{*}{$\begin{array}{l}\text { Spesialis } \\
\text { Koding Klinis }\end{array}$} & MIK 111 & Biologi dan Genetika \\
\hline & MIK 212 & Anatomi dan Fisiologi 1 \\
\hline & MIK 311 & Anatomi dan Fisiologi 2 \\
\hline & MIK 213 & Patologi 1 \\
\hline & MIK 314 & Patologi 2 \\
\hline & MIK 215 & Terminologi Medis 1 \\
\hline & MIK 312 & Terminologi Medis 2 \\
\hline & MIK 216 & KКРMT I \\
\hline & MIK 313 & KKРMT II \\
\hline & MIK 414 & ККРMT III \\
\hline & MIK 511 & AuditdanEvaluasi Koding Klinis \\
\hline & MIK 612 & $\begin{array}{l}\text { Koding KIinis dan } \\
\text { Reimbursement }\end{array}$ \\
\hline
\end{tabular}


Hosizah. Model Kurikulum Program Studi S-1 Manajemen Informasi Kesehatan Berbasis ...

\begin{tabular}{|c|c|c|}
\hline Profil Lulusan & Kode MK & Nama M K \\
\hline \multirow{11}{*}{$\begin{array}{l}\text { Analis Data } \\
\text { dan Manajer } \\
\text { Informasi } \\
\text { Kesehatan }\end{array}$} & UST 153 & Statistik I (Statistik Deskriptif) \\
\hline & ESA 155 & Statistik II (Statistik Inferens) \\
\hline & MIK 422 & Statistik dalam MIK \\
\hline & MIK 521 & Epidemiologi dan Surveilance \\
\hline & MIK 522 & $\begin{array}{l}\text { Aspek Hukum dal amPelayanan } \\
\text { Kesehatan }\end{array}$ \\
\hline & MIK 623 & $\begin{array}{l}\text { Analisis dan Teknik Presentasi } \\
\text { Data }\end{array}$ \\
\hline & MIK 624 & Sistem Informasi Geografis \\
\hline & MIK 721 & Anal isis dan Teknik Pemodelan \\
\hline & MIK 722 & $\begin{array}{l}\text { Proteksi dan Pertukaran } \\
\text { Informasi Kesehatan }\end{array}$ \\
\hline & MIK 723 & Manajemen Data Penelitian \\
\hline & MIK 625 & $\begin{array}{l}\text { Tata Kelola Sistem dan } \\
\text { Informasi Kesehatan }\end{array}$ \\
\hline \multirow{6}{*}{$\begin{array}{l}\text { Manajer Unit } \\
\text { Kerja MIK } \\
\text { (RMIK) }\end{array}$} & MIK 331 & Teori dan Perilaku Organisasi \\
\hline & MIK 432 & Manajemen Mutu dan Risiko \\
\hline & MIK 631 & $\begin{array}{l}\text { Standar Akreditasi Pelayanan } \\
\text { Kesehatan }\end{array}$ \\
\hline & MIK 532 & $\begin{array}{l}\text { Manajemen Sumber Daya } \\
\text { Manusia }\end{array}$ \\
\hline & MIK 633 & $\begin{array}{l}\text { Disain Kerja dan Peningkatan } \\
\text { Proses MIK }\end{array}$ \\
\hline & MIK 634 & Manajemen Keuangan \\
\hline \multirow{7}{*}{$\begin{array}{l}\text { Spesialis } \\
\text { Clinical } \\
\text { Documentation } \\
\text { Improvement } \\
\text { (CDI) }\end{array}$} & MIK 141 & $\begin{array}{l}\text { Konsep Dasar MIK (Rekam } \\
\text { Medis) }\end{array}$ \\
\hline & MIK 242 & $\begin{array}{l}\text { Standar Isi dan Pen- } \\
\text { dokumentasian RM }\end{array}$ \\
\hline & MIK 341 & $\begin{array}{l}\text { Pengel olaan Paper-based } \\
\text { RekamMedis }\end{array}$ \\
\hline & MIK 541 & Audit Dokumentasi Klinis 1 \\
\hline & MIK 642 & Audit Dokumentasi Klinis 2 \\
\hline & MIK 442 & RekamKesehatan Elektronik 1 \\
\hline & MIK 543 & RekamKesehatan Elektronik 2 \\
\hline \multirow{6}{*}{$\begin{array}{l}\text { Inisiator } \\
\text { Perancang dan } \\
\text { Pengembang } \\
\text { Electronic } \\
\text { Health Records } \\
\text { (EHR)/ } \\
\text { Electronic } \\
\text { Medical } \\
\text { Records } \\
\text { (EMR) }\end{array}$} & MIK 151 & $\begin{array}{l}\text { Pengantar Teknol ogi Informasi } \\
\text { Komunikasi }\end{array}$ \\
\hline & MIK 252 & Algoritma dan Pemrograman \\
\hline & MIK 351 & $\begin{array}{l}\text { Manajemen Basis Data dan } \\
\text { Aplikasi dalam MIK }\end{array}$ \\
\hline & MIK 551 & Perancangan Sistem Informasi \\
\hline & MIK 751 & $\begin{array}{l}\text { Standarisasi Data dan } \\
\text { Interoperabilitas }\end{array}$ \\
\hline & MIK 452 & $\begin{array}{l}\text { Analisis dan Evaluasi Sistem } \\
\text { Informasi }\end{array}$ \\
\hline
\end{tabular}

\section{SIMPULAN}

5 (lima) profil lulusan Program S-1 Manajemen Informasi Kesehatan (MIK) meliputi: Spesialis Koding Klinis, Analis Data dan Manajer Informasi Kesehatan, Manajer Unit Kerja Manajemen Informasi Kesehatan (Rekam Medis dan Informasi Kesehatan), Spesialis Clinical Documentation Improvement (CDI), Inisiator Perancang dan Pengembang Rekam Kesehatan Elektronik (Electronic Health Records) atau Rekam Medis Elektronik (Electronic Medical Records). Masa pendidikan ProgramStudi S-1 MIK Universitas Esa Unggul adalah 8 (delapan) semester. Beban Belajar mahasiswa program studi S-1 MIK Universitas Esa Unggul 144 sks, terdiri dari MK Wajib 136 sks dan MK Pilihan 8 sks. Distribusi tahapan beban belajar per tahun sebagai berikut: Tahun I (38 sks), Tahun II (40 sks), Tahun III (42 sks), dan Tahun IV (24 sks). Total beban studi teori adalah 92 sks dan praktik/ praktek adalah 52 sks.

\section{DAFTAR PUSTAKA}

Atmodjo Djoti, Komisi Akreditasi RS (KARS), 2013. Kompetensi Perekam Medis dalam Manajemen RS. Sosialisasi Rencana Pelaksanaan Pembelajaran (RPP) Kurti D3 RMIK dan Workshop Penyusunan Kurikulum D4 MIK, Bandung 2 September.

Bailey J, Rudman WJ , 2004. The Expanding Roleof the HIM Professional: Where Research and HIM Roles Intersect. Perspectives in Health Information Management 1; 7, Fall.

CAHIIM (Commission Accreditation on Health Informatics and Information Management). HIM Baccal aureate Degree Curriculum Requirements. Artike elektronik, diakes 15 J anuari 2016. http://www.cahiim.org/him/ curriculumrequirements.html

Dedy K, Hosizah, 2014. Peran Perekam Medis (Profesional Manajemen Informasi Kesehatan) dalam Implementasi INA-CBG's di BLUD H. Boejasin Pelaihari. Jurnal Manajemen Informasi Kesehatan Indonesia (J MIKI) |ISSN 2337-585X Nolume1, Maret.

Direktoratj enderal PembelajarandanKemahasiswaan, Kementerian Riset Teknologi dan Pendidikan Tinggi, Maret 2016. Panduan Penyusunan KurikulumPendidikan Tinggi. 
FliteCA, Harman LB, 2013. CodeofEthics: Principles for Ethical Leadership. Perspectivesin Health Information Management, Winter.

Global Health Workforce Council (GHWC), 2016. American Heal th Information Management Association (AHIMA)-International Federation Health Information Management Association (IFHIMA), Global Academic Curricula Competencies for Health Information Professionals.

Hosizah, 2015. Health Information Management Education in Indonesia. International Federation of Heal thI Information Management Associations (IFHIMA) Newsletter |Global News, May No. 2.

Hosizah, 2013. Analisis Sebaran Sumber Daya Manusia dan Kegiatan Pelayanan Rekam Medis dan Informasi KesehatanBerdasarkan Rifaskes 2011. Jurnal Manajemen Informasi Kesehatan Indonesia (J MIKI) | ISSN 2337-585X Nolume 1, Maret, page: 85

Houser SH, Manger BJ , Price BJ , Silvers C, Susan $H, 2009$. Expanding the Health Information Management Public Heal th Role Perspectives in Health Information Management6, Summer.

Perhimpunan Profesional Perekam Medis dan Informasi Kesehatan Indonesia (PORMIKI), 2015. Standar Kompetensi Perekam Medis dan Informasi Kesehatan, Hasil Kongres VIII, Makassar.
Permenristekdikti No. 44Tahun2015 tentangStandar Nasional Pendidikan Tinggi (SN-Dikti)

Peraturan Presiden Republik Indonesia Nomor 8 Tahun 2012 tentang Kerangka Kualifikasi Nasional Indonesia (KKNI).

Peraturan Menteri Pendayagunaan A paratur Negara Reformasi Birokrasi (Permenpan-RB) No. 30 Tahun 2013 tentang Jabatan Fungsional Perekam Medis dan Angka Kreditnya.

Rudman WJ , 2016. AHIMA Foundation and GHWCGlobal Currirula, $1^{\text {st }}$ International Meeting on Health Information Management ( $1^{\text {st }}$ ISMoHIM), Yogyakarta 27-28 J uni.

Safian SC, 2012. Factors Influencing Students to Enroll in Health Information Management Programs. Perspectivesin Heal th I nformation Management, Summer.

University of Pittsburgh, 2015. Bachel or of Science Health Information Management Curriculum. Department of Health Information Management, School of Health and Rehabilitation Sciences.

Watzlaf VJM, Rudman WJ, Susan H., Ping Ren, 2009. The Progression of the Roles and Functions of HIM Professionals: A Look into the Past, Present, and Future. Perspectives in Heal th I nformation Management 6, Summer. 